\title{
www.jsrd.org.pk
editor@jsrd.org.pk \\ IMPACT OF AUDIO-VISUAL AIDS ON TEACHING LEARNING PROCESS OF ENGLISH LANGUAGE AT PRIMARY LEVEL
}

Irfan Ullah Khan ${ }^{1}$, Muhammad Saqib Khan ${ }^{2}$ \& Haroon Rehan ${ }^{3}$

${ }^{1}$ Institute of Education and Research, The University of Lakki Marwat, KP, Pakistan

${ }^{2}$ Department of Business Administration, Gomal University, Dera Ismail Khan, Pakistan

${ }^{3}$ Department of Public Administration, Gomal University, Dera Ismail Khan, Pakistan

\begin{tabular}{l|l}
\hline KEYWORDS & \multicolumn{1}{l}{ ABSTRACT } \\
\hline $\begin{array}{l}\text { English Language } \\
\text { Leaching }\end{array}$ & $\begin{array}{l}\text { English is an international language and plays a pivotal role in our education } \\
\text { system that is why different methods are used for English language teaching } \\
\text { learning process at primary level to improve learning teaching process, that } \\
\text { is why the present study was conducted to highlight the audio-visual aids' } \\
\text { role in process of teaching learning at the level of primary education. All the } \\
\text { teachers and head teachers of Southern Districts Primary schools in Khyber } \\
\text { Pakhtunkhwa were study population. The study sample consisted of } 100 \\
\text { head-teachers (50 female and 50 male) and 300 teachers (150 males \& 150 } \\
\text { females). By nature, the study was survey, researcher developed personally } \\
\text { instrument to collect data from respondents and thus analyzed, tabulated, } \\
\text { and construed the data in the light of study objectives. The statistical tools } \\
\text { like mean and SD were used for data analysis. The present study highlighted } \\
\text { that audio visual aids make the learners able learn English language easily } \\
\text { and in an interested way. }\end{array}$ \\
\hline Corresponding Author & $\begin{array}{l}\text { Irfan Ullah Khan, Email: thescholaredun@yahoo.com } \\
\text { https://doi.org/10.53664/JSRD/01-01-2020-06-71-77 }\end{array}$ \\
\hline DOI &
\end{tabular}

\section{INTRODUCTION}

The audio-visual aids usage in the teaching-learning process is common now-a-days and particularly in teaching of languages like English language it is very common and plays dominant role in English language learning. In the teaching learning process, the standing of audio-visual aids is clear due to this reason that it makes process of teaching learning enjoyable and interesting for learners. When teacher use various audio-visual aids during teaching then students give more attention to it and learn more and more in this way because it makes the learners to see or watch the real image of anything compare to only theoretical discussion (Çakir, 2006). This study aimed to examine the audio-visual aids on teaching learning process of English language at primary level in particular context under considerations. it means that audio-visual-aids are useful both for teachers and learners 
since it facilitates the both teachers and learners during the teaching learning process and develops language skills of learners.

Audio visual aids are basically the two separate things audio aids refers to those materials which may be heard and recorded in the audio form like tape recorder, or record of any dialogue, speech or song and it may be used in language classrooms, but on the other hand visual aids refers to those materials which we may be perceived like poster, pictures, videos, graphics, flash cards and charts (Asokhia, 2009). In this connection, in light of the above detail, it is clear that both of these materials are successfully used in the language learning classrooms as audio materials are successfully used for student pronunciation development, students may listen different audio speeches and correct pronunciation of words in order to correct their pronunciation according to the recorded sound. Similarly, on the other hand, the visual aids are also very helpful for the learners since it makes the minds of the learners when a child see something and learn its meaning or name then it becomes the part of his/her memory.

\section{LITERATURE REVIEW}

Audio visual aids are successfully used in the communicative teaching language though language communicative teaching is one of most recent modern methods of the teaching English language. In this method of the teaching language is the learning in day-to-day communication related to real life situations that is in this method of teaching different audio-visual aids are may be used successfully to make language learning process more effective and interested for learners. The learners are engaged in the various audio-visual materials like maps, pictures (Freeman, 2000). Similarly, Mathew and Alidmat (2013) they have led the study on audio-visual aids usefulness and finally concluded that these audiovisual aids are useful material in the English language learning classrooms. These materials facilitate the learners and making the teaching learning process interested not only for the learners but also for teachers. It means that audio visual aids are caring material for English language teaching and may not be neglected their role in the English language learning. Corbeil (2007) also highlighted in his study that learners use power point for brightness, liveliness, and interactivity and clarity.

Power point makes learning process interactive for learners and helps them to understand in an interested way because there are visual examples for learners which make the minds of learners and motivate them. Ranasinghe and Leisher (2009) clearly mentioned that the technology use can never be replaced to the human mind but it may be used as a helpful material and facilitate leaners in teaching learning process. There are various audio-visual aids which can help learners to learn more and more in an interested way. Thus, the audiovisual-aids use is helpful particularly at primary level because at this the learners' level is low and when teacher use audio visual aids then learner's response towards these materials. Gilakjani (2011), dyed various problems confronted by English language learners 
in learning and these difficulties may be rectified over proper audio-visual-aids use since if teacher continuously audio-visual-aids use in classrooms in order to help the learners to correct their pronunciation, stress, intonation. Thus, in light of above detail it may not be wrong to say that most of learners' difficulties can be easily solved while using audio visual aids for this purpose to make the leaners able to improve their English language learning in an easy and interested manner.

Jadal (2011) also highlighted the audio-visual-aids effectiveness in English teaching at the primary level. It is clear in light of previous research regarding the role of audio-visual aids in English language teaching that are quite helpful for learning language English. These audio-visual aids are not only obliging for learners but also for teachers since it facilitates teachers in teaching learning process. Maniruzzaman and Rahman (2008) conducted the study in Bangladesh on audio aids use in EFL classroom at tertiary-level and recommend that the insufficiency of the audio material and equipment, teacher training lacking, and insignificance of disappointed and uninterested with the EFL materials related with courses when they find it unattractive, difficult, unfamiliar, mechanical, as well as problematic. The environment of classroom should creativity stimulate, mature constructive values, attitudes and interests for learning effectively. The activities and tasks need to be aimed to build essential skills such as independent study and capacity to think and judge for one and for all. In this connection, according to Lam (2000), the teachers' particular values towards the advantages of the technology using for the teaching language effect the teacher decision concerning technology utilization.

\section{RESEARCH METHODS}

The major determination of current study was to investigate the audio-visual aids' role in teaching learning process at Primary level towards English language in Bannu District, KP, Pakistan. The study in nature was survey type as well as descriptive. All the teachers and head-teachers of primary schools (government) in the southern five (5) districts in Khyber Pakhtunkhwa were selected as study population. Study sample includes 300 teachers and 100 heads-teachers randomly selected from Khyber Pakhtunkhwa southern districts. For the data collection, scholar developed two questionnaires personally which were validated over pilot-testing before distributing to respondents of present study. The collected data over administering questionnaires after pilot-testing from sample from entire population was analyzed by using different statistical tools. For this purpose, personally researcher go to institutions (sample $\&$ respondents. Therefore, collected data over research instruments was analyzed, tabulated, and interpreted using statistical tools like standard deviation and mean in the light of study objectives.

\section{DATA ANALYSIS}

The data collected through questionnaire was thus analyzed, tabulated, and understood over standard deviation and mean in order to meet the objectives of current study. In this 
connection, the suitable most statistical techniques like standard deviation, mean, mean standard error and the population estimated mean which are thus commonly used in the educational research to obtained the desired information was consequently applied for obtaining the desired outcomes.

Table 1 Views of Learners about Audio Visual Aids

\begin{tabular}{lccccccccc}
\hline \multicolumn{1}{c}{ Statement } & SEx & M & SA & A & UD & DA & SDA & M & SD \\
\hline $\begin{array}{l}\text { Audio visual aids make teaching } \\
\text { learning process interested for learners }\end{array}$ & .033 & $1.33---1.46$ & 272 & 105 & 16 & 5 & 2 & 1.40 & 0.67 \\
$\begin{array}{l}\text { Audio visual aids are helpful in English } \\
\text { language teaching. }\end{array}$ & .027 & $1.19---1.30$ & 318 & 69 & 8 & 5 & 23 & 1.25 & 0.55 \\
$\begin{array}{l}\text { Audio visual aids arouse the interest of } \\
\text { learners for English learning. }\end{array}$ & .031 & $1.24---1.37$ & 302 & 81 & 9 & 7 & 1 & 1.31 & 0.62 \\
$\begin{array}{l}\text { Audio visual aids are useful both for } \\
\text { teachers and leaners }\end{array}$ & .020 & $1.10---1.18$ & 348 & 49 & 35 & 13 & 6 & 1.14 & 0.41 \\
$\begin{array}{l}\text { Audio visual aids are helpful at primary } \\
\text { level. }\end{array}$ & .058 & $1.70---1.92$ & 245 & 52 & 38 & 62 & 3 & 1.81 & 0.16 \\
$\begin{array}{l}\text { Audio visual aids facilitate students to } \\
\text { correct English words pronunciations }\end{array}$ & .029 & $1.23---1.34$ & 307 & 67 & 12 & 11 & 5 & 1.28 & 0.54 \\
$\begin{array}{l}\text { Audio visual aids facilitate students to } \\
\text { develop English language reading skills }\end{array}$ & .048 & $1.51---1.71$ & 256 & 79 & 28 & 34 & 2 & 1.61 & 0.97 \\
$\begin{array}{l}\text { Audio visual aids facilitate students to } \\
\text { learn English language writing skills }\end{array}$ & .035 & $1.32---1.45$ & 283 & 90 & 17 & 8 & 2 & 1.39 & 0.71 \\
$\begin{array}{l}\text { Audio visual aids facilitate students to } \\
\text { increase English language vocabulary }\end{array}$ & .056 & $1.94---2.16$ & 162 & 116 & 74 & 33 & 15 & 2.05 & 1.12 \\
\hline $\begin{array}{l}\text { Audio visual aids facilitate students to } \\
\text { improve speaking in English language. }\end{array}$ & .076 & $2.70---3.00$ & 128 & 42 & 67 & 85 & 78 & 2.85 & 1.53 \\
\hline
\end{tabular}

The above table clearly indicates views of learners (respondents) about the audio-visual aids' usefulness in learning teaching process of English learning language at primary level. Most of views are in agree and strongly agree it means that audio-visual-aids are helpful in learning teaching process at primary level education. In first statement "strongly agree 272 , agree 105 , undecided 16 , disagree 5 , strongly disagree $2^{\text {", in }} 2^{\text {nd }}$ statement "strongly agree 318 , agree 69 , undecided 8 , disagree 5 , strongly disagree" 23 , in the third statement "strongly agree 302 , agree 81 , undecided 9, disagree 7, strongly disagree" 1 , in the fourth statement "strongly agree 348 , agree 49 , undecided 35 , disagree 13 , strongly disagree" 6 , in the fifth statement "strongly agree 245 , agree 52 , undecided 38 , disagree 62 , strongly disagree" 3 respectively.

Similarly, in the sixth statement "strongly agree 307 , agree 67 , undecided 12 , disagree 11 , strongly disagree" 5 , in seventh statement "strongly agree 256, agree 79, undecided 28 , disagree 34 , strongly disagree" 2 , in the eighth statement "strongly agree 283 , agree 90 , undecided 17, disagree 8, strongly disagree" 2 , in the ninth statement "strongly agree 162 , agree 116 , undecided 74 , disagree 33 , strongly disagree" 15 , in the last statement "strongly agree 128 , agree 42 , undecided 67 , disagree 85 , strongly disagree" 78 . In this connection, consequently, in light of the above result the importance of audio-visual aids may not be 
Khan, Khan \& Rehan... Impact of Audio-Visual Aids

neglected but it shows that audio visual aids are quite helpful in English language learning process at primary level.

\section{RESULTS OF STUDY}

From data analysis, the following results were drawn by interpreting the data in order to extract the desired information leading towards the objectives of the current research study.

1. The mean "rating score and standard deviation of respondents on the second statement were 1.25 and 0.55 respectively hence, majority of respondents looked strongly agree" to this statement.

2. The mean "rating score and standard deviation of the respondents on the 1st statement were 1.40 and 0.67 respectively hence, majority of respondents looked strongly agree" to this statement.

3. The mean "rating score and standard deviation of the respondents on fourth statement were 1.14 and 0.41 respectively hence, majority of respondents looked strongly agree" to this statement.

4. The mean "rating score and standard deviation of respondents on third were 1.31 and 0.62 respectively hence, majority of the respondents looked strongly agree" to this statement.

5. The mean "rating score and standard deviation of respondents on sixth statement were 1.28 and 0.58 respectively hence, majority of respondents looked strongly agree" to this statement.

6. The mean "rating score and standard deviation of respondents on fifth statement were 1.18 and 1.16 respectively hence, majority of respondents looked strongly agree" to this statement.

7. The mean "rating score and standard deviation of respondents on eight statement were 1.39 and 0.71 respectively hence, majority of respondents looked strongly agree" to this statement.

8. The mean "rating score and standard deviation of respondents on nine statement were 2.05 and 1.17 respectively hence, majority of respondents looked agree" to this statement.

9. The mean "rating score and standard deviation of respondents on seven statement were 1.61 and 0.97 respectively hence, majority of the respondents looked strongly agree" to this statement.

10. The mean "rating score and standard deviation of the respondents on the last statement were 2.85 and 1.53 respectively hence, majority of respondents looked undecided" to this statement.

\section{CONCLUSIONS}

The following conclusions were made on the basis of results of study from the statistical procedures: 
Khan, Khan \& Rehan... Impact of Audio-Visual Aids

1. Audio visual aids are provided by the government to majority of schools in order to motivate learners regarding the school activities and to promote the teaching learning process at primary level.

2. Majority of respondents opined that audio-visual-aids are necessary for teaching process of English language at the primary level because it makes the teaching learning process interested at primary level.

3. Majority of respondents viewed that audio-visual-aids are available in schools but if new multi-media-based teaching learning is introduced at primary then it will more beneficial for learners as compare to the traditional methods of the teaching learning at primary level.

\section{Recommendations}

In light of results and conclusions, following suggestions and recommendations have been extracted by researcher.

1. Findings of the present study revealed that audio-visual-aids are quite helpful in learning teaching process of English language at primary level that is government should provide audio visual aids to all primary schools.

2. In light of the findings of the study it may be quite fruit full to give in service training especially to primary level teachers that how they should use various audio-visual aid during teaching learning of English language.

3. Findings of study clearly highlighted that audio-visual-aids make learning teaching process interested for learner and remove their boredom during teaching learning process.

\section{REFERENCES}

Corbeil, G. (2007). Can PowerPoint presentations effectively replace textbooks and blackboards for teaching grammar? Do students find them an effective learning tool? Calico Journal, 24(3), 631-656.

Çakir, D. I. (2006). The use of video as an audio-visual material in foreign language teaching classroom. The Turkish Online Journal of Educational Technology, 5(4), 6772.

Asokha, M.O. (2009). Improvisation/teaching aids: aid to effective teaching of English language. International Journal of Educational Sciences, 1(2), 79-85.

Freeman, D. L. (2000). Techniques and principles in language teaching. New York: Oxford University Press.

Mathew, N. G., \& Alidmat, A.O.H. (2013). A study on the usefulness of audio-visual aids in EFL classroom: Implications for effective instruction. International Journal of Higher Education, 2(2), 86-91. 
Khan, Khan \& Rehan... Impact of Audio-Visual Aids

Jadal, M. M, (2011). A study of effectiveness of the audio-visual-aids in teaching and learning of English at primary level in Z.P. Primary Schools of Solapur District. Indian Streams Research Journal, I (VII).

Lam, Y. (2000). Technophilia vs. technophobia: A preliminary look at why second-language teachers do or do not use technology in their classrooms. Canadian Modern Language Review, 56 (3), 390-420.

Maniruzzaman, M., \& Rahman, M. M. (2008). The use of audio aids in the EFL Class at the tertiary level: A plus or a minus? Daffodil University International Journal of Business and Economics, 3 (1), 121-137.

Gilakjani, A. B. (2011). A study on the situation of pronunciation instruction in ESL/EFL classrooms. Journal of Studies in Education, 1, (1), 1-15.

Ranasinghe, A. I. \& Leisher, D. (2009). The benefit of integrating technology into the classroom. International Mathematical Forum, 4, (40), 1955-1961. 